\title{
SPECIALLY PROTECTED NATURAL AREA «SOURCES OF THE KRYMZA RIVER»: MODERN STATE AND PROTECTION OF (SYZRANSKY DISTRICT, SAMARA REGION)
}

(C) 2016

\author{
S.V. Saksonov, doctor of biological sciences, professor, \\ deputy director for science, head of the Laboratory of Problems of Phytodiversity \\ Institute of Ecology of the Volga River Basin of the Russian Academy of Sciences, Togliatti (Russia) \\ L.A. Novikova, doctor of biological sciences, \\ professor of the Chair of General Biology and Biochemistry, chief researcher \\ Penza State University, Penza (Russia)
}

A.E. Mitroshenkova, candidate of biological sciences,

associate professor of the Chair of Biology, Ecology and Methods of Teaching

Samara State University of Social Sciences and Education, Samara (Russia)

N.S. Rakov, candidate of biological sciences, researcher of the Laboratory of Problems of Phytodiversity Institute of Ecology of the Volga River Basin of the Russian Academy of Sciences, Togliatti (Russia)

S.A. Senator, candidate of biological sciences, senior researcher of the Laboratory of Problems of Phytodiversity Institute of Ecology of the Volga River Basin of the Russian Academy of Sciences, Togliatti (Russia)

G.V. Dronin, postgraduate student of the Laboratory of Problems of Phytodiversity Institute of Ecology of the Volga River Basin of the Russian Academy of Sciences, Togliatti (Russia) A.A. Golovlev, doctor of geographical sciences, professor of the Chair of Ecology and Life Safety Samara State University of Economics, Samara (Russia)

Abstract. In the article contains information about present state of specially protected natural area, natural monument of regional significance «Sources of the Krymza River» (Syzransky District, Samara Region), its flora, vegetation and rare plant species. Phytocenotic diversity represented by 9 types of plant communities. Marge complex is formed by Bromopsis riparia + variiherbetum, Carex acuta + variiherbetum and Calamagrostis epigeios +variiherbetum communities. In the upper part of the river Krymzy laid on geobotanical profile ravine in the direction from left to right slope communities are located in the profile as follows: Quercus robur-Corylus avellanaAegopodium podagraria $\rightarrow$ Tilia cordata-Corylus avellan-variiherbetum $\rightarrow$ Acer platanoides-Urtica dioica $\rightarrow$ Acer platanoides-Corylus avellana-Carex pilosa $\rightarrow$ Quercus robur-Brachypodium pinnatum $\rightarrow$ Populus tremulaCalamagrostis epigeios; bordered the profile on both sides of the community Calamagrostis epigeios + variiherbetum. The floristic diversity of the territory is represented by 337 species of vascular plants belonging to 199 genera, 59 families and 4 department. The flora 1 species (Iris aphylla) is included in the Red Book of Russia, and 12 species - in the Red Book of Samara Region: Drymochloa sylvatica, Gymnocarpium dryopteris, Laser trilobum, Maianthemum bifolium, Matteuccia struthiopteris, Athyrium filix-femina, Bromopsis benekenii, Crataegus volgensis, Epipactis helleborine, Helichrysum arenarium, Iris aphylla and Primula macrocalyx. These data show that modern state of the natural monument «Sources of the Krymza River» characterized by stability floral and phytocenotic indicators. Economic exploitation is here reduced to only traditional for him to collect berries locals, run cattle and fire protection.

Keywords: specially protected natural area; rare species; natural monument; Sources of the Krymza River; phytocoenotic diversity; floristic diversity; Red data book of Samara Region; Middle Volga Region; Samara Region; Syzransky District; Krymza.

\section{УДК 595.422, 599}

\section{ФАУНА ГАМАЗОВЫХ КЛЕЩЕЙ (GАМАSОIDEA) МЕЛКИХ МЛЕКОПИТАЮЩИХ ПРИРОДНО-ТЕРРИТОРИАЛЬНОГО КОМПЛЕКСА «САМАРСКАЯ ЛУКА»}

(C) 2016

\author{
И.А. Сорокопуд, аспирант кафедры экологии и охраны окружающей среды \\ Самарская государственная областная академия (Наяновой), Самара (Россия)
}

Аннотащия. В статье приводятся данные о фауне гамазовых клещей, паразитирующих на мелких млекопитающих. Данные получены в ходе многолетнего мониторинга экологического комплекса мелких млекопитающих природно-территориального комплекса «Самарская Лука», реализующегося с 1999 г. Обобщены и проанализированы данные о фауне гамазид за 14 лет исследований (2000-2003, 2005, 2007-2015 года), включая литературные данные о гамазовых клещах данной территории. Определена видовая принадлежность 7439 особей гамазид, относящихся к пятнадцати видам семи родов трех семейств. Установлено паразитирование гамазовых клещей на 16 видах мелких млекопитающих, относящихся к отрядам Грызуны, Землеройкообразные, Хищные (ласка).

Выявлены доминирующие виды клещей, так, к эудоминантам относятся Laelaps hilaris и Hirstionyssus isabellinus, к доминантам - Hirstionyssus ellobii, Haemolaelaps glasgowi, Hyperlaelaps arvalis, L. agilis. Крайне редкими видами, встреченными в единичных экземплярах, оказались Myonyssus rossicus, L. algericus, Haemogamasus ambulans и Hirstionyssus macedonicus. Впервые для данной территории отмечены H. ellobii, L. micromydis, H. ambulans, H. macedonicus. 
Сорокопуд И.А.

Фауна гамазовых клещей (Gamasoidea) мелких млекопитающих...

03.02.00 - общая биология

Сделаны выводы о степени приуроченности паразитов к определенным видам хозяев. Моногостальные виды: L. agilis (хозяин - желтогорлая мышь), L. muris (хозяин - водяная полевка), L. micromydis (хозяин - мышьмалютка), L. algericus (хозяин - мышь домовая), H. ellobii (хозяин - слепушонка обыкновенная), H. arvalis (хозяин - полевка-экономка и водяная полевка). Полигостальные: H. musculi, L. hilaris, H. isabellinus, H. glasgowi, E. stabularis, H. nidi.

Ключевые слова: гамазовые клещи; экологический мониторинг; мелкие млекопитающие; Самарская Лука; Самарская область; паразиты; паразито-хозяинные комплексы; грызуны; насекомоядные; землеройки; зараженность; индекс обилия; экстенсивность инвазии; степень доминирования; паразито-хозяинная приуроченность.

Гамазовые клещи характеризуются широким набором биотопов, заселяя почву, лесную подстилку, мох, гнезда птиц и млекопитающих, места хранения человеком запасов продуктов питания. Особое внимание исследователей привлекают паразитические гамазовые клещи, связанные с птицами и млекопитающими, так как представители этой группы могут являться хранителями и возбудителями инфекционных заболеваний.

Для большинства гамазид хозяевами являются млекопитающие, в частности мышевидные грызуны и насекомоядные. Паразито-хозяинные комплексы «мышевидные грызуны - гамазовые клещи» имеют существенное эпидемиологическое и эпизоотологическое значение. Существует мнение, что паразитические гамазиды являются существенным фактором в поддержании и распространении многих природноочаговых инфекций, поражающих как диких, так и домашних животных, тем самым, косвенно, воздействуя и на человека (туляремия, чума, ГЛПС, лептоспироз, риккетсиоз, лихорадка Ку и др.) [1]. Некоторые авторы отмечали зависимость природной очаговости этих заболеваний от характера распространения паразитических гамазовых клещей [2].

Знание структуры и динамики сообществ гамазовых клещей, переносчиков инвазий и инфекций, важно как для прогнозирования и профилактики заболеваемости этими инфекциями людей и домашних животных, так и для возможности создания прогностических моделей динамики паразито-хозяинных комплексов. Также интересным представляется изучение эктопаразитов и их взаимосвязей с хозяевамипрокормителями для формирования представлений об изменениях фауны в результате техногенного пресса и климатических изменений.

В литературе имеется немало сведений о гамазовых клещах на территории России, их экологии, структуре сообществ, динамике численности, распространении и т.д. [2; $3 ; 4 ; 5 ; 6 ; 7]$.

Однако сведений о сообществах гамазид на территории Самарской области или соседних территорий имеется очень мало и они достаточно фрагментарны. На территории национального парка «Самарская Лука» и Жигулёвского государственного заповедника Н.Ю. Кириллова и А.А. Кириллов исследовали состав фауны эктопаразитов грызунов и насекомоядных, в том числе гамазовых клещей, в 20012004 годах [8; 9]. В связи с этим представляется целесообразным изучение фауны и экологии гамазид на территории Самарской области.

Целью наших исследований на данном этапе явилось установление наиболее полного видового списка гамазовых клещей, паразитирующих на мелких млекопитающих на территории природно-территориального комплекса «Самарская Лука».
Для изучения современного состояния вопроса Самарской государственной областной академией (Наяновой) в 1999-2016 гг. регулярно организуются мониторинговые исследования экологического комплекса мелких млекопитающих на территории природно-территориального комплекса «Самарская Лука». Данная работа отражает часть результатов этих исследований.

Для настоящей работы использованы гамазовые клещи, собранные с мелких млекопитающих на территориях национального парка «Самарская Лука», Жигулёвского государственного заповедника, промышленных зон города Тольятти в 2000-2015 гг. За исключением 2004 и 2006 годов. Отловы проводились ежегодно в весенний, летний и осенний периоды на стационарных площадках мониторинга.

Использовалась методика безвозвратного отлова методом ловчих канавок с установленными в них живоловками [10] на стационарных площадках [11; 12]. Обработку, фиксацию и определение паразитических членистоногих проводили по стандартным методикам [13].

Было отловлено и очесано 4333 особи мелких млекопитающих 16 видов: Microtus arvalis Pallas, 1778 (обыкновенная полевка), Sorex araneus Linnaeus, 1758 (обыкновенная бурозубка), Sorex minutus Linnaeus, 1766 (малая бурозубка), Micromys minutus Pallas, 1771 (мышь-малютка), Apodemus uralensis Pallas, 1811 (мышь лесная), Myodes glareolus Schreber, 1780 (рыжая полевка), Ellobius talpinus Pallas, 1770 (слепушонка обыкновенная), Microtus oeconomus Pallas, 1776 (полевка-экономка), Arvicola terrestris Linnaeus, 1758 (водяная полевка), Mus musculus Linnaeus, 1758 (мышь домовая), Mustela nivalis Linnaeus, 1766 (ласка), Neomys fodiens Pennant, 1771 (кутора), Apodemus flavicollis Melchior, 1834 (мышь желтогорлая), Talpa europaeus Linnaeus, 1758 (крот), Crocidura suaveolens Pallas, 1811 (белозубка малая), Apodemus agrarius Pallas, 1771 (мышь полевая). Видовую принадлежность млекопитающих устанавливали по определителю Н.А. Бобринского, Б.А. Кузнецова, А.П. Кузякина [14].

Следует отметить, что к «обыкновенной полевке» на данном этапе исследований условно отнесены виды-двойники Microtus arvalis и Microtus rossiaemeridionalis (levis), возможности надежно диагностировать которых в полевых условиях у нас отсутствовали.

С отловленных животных собрано 8448 экземпляров гамазовых клещей, относящихся к 15 видам, 7 родам и 3 семействам (Laelaptidae, Liponyssidae, Haemogamasidae). 68\% собранных гамазид принадлежат двум самым многочисленным родам - род Laelaps и род Hirstionyssus. Нимфальные стадии клещей учитывались нами отдельно, так как определе- 
ние видовой принадлежности протонимф и дейтонимф для многих видов невозможно в виду отсутствия определительных таблиц.

Оценивались такие характеристики зараженности, как индекс обилия, отражающий среднюю численность паразитов и экстенсивность инвазии, в \%, для определения числа пораженных животных конкретным видом паразита.

Для установления степени доминирования видов в сообществе гамазовых клещей на территории Са- марской Луки, использовалась система, предложенная Райским: эудоминант - более $15 \%$ от общего числа в сборах, доминант - 5,1-15\%, субдоминант - 2,1$5 \%$, редкий - 1,1-2\%, крайне редкий - менее $1,1 \%$.

Обобщенные данные, включающие информацию о видовой приуроченности гамазовых клещей и мелких млекопитающих-хозяев в Среднем Поволжье и на Самарской Луке, интегрирующие литературные данные и результаты наших исследований, приведены в табл. 1.

Таблица 1 - Встречаемость гамазовых клещей на мелких млекопитающих Среднего Поволжья

\begin{tabular}{|c|c|c|c|c|c|c|c|c|c|c|c|c|c|c|c|c|}
\hline & 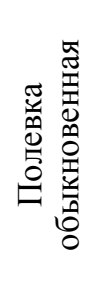 & 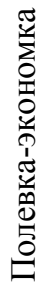 & 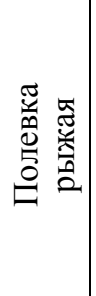 & 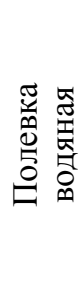 & 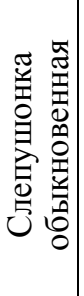 & 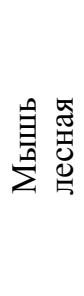 & 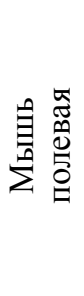 & 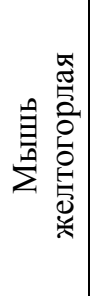 & 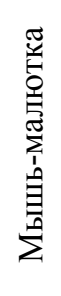 & 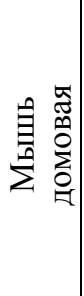 & 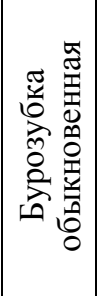 & 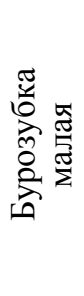 & 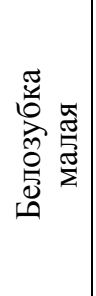 & 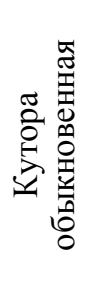 & 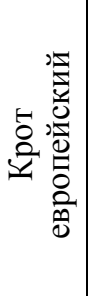 & 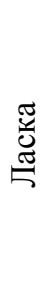 \\
\hline Laelaps hilaris & $\begin{array}{c}+[9 \\
15]\end{array}$ & + & $\begin{array}{c}+ \\
{[15]}\end{array}$ & $\begin{array}{c}+ \\
{[9]}\end{array}$ & + & $\begin{array}{c}++ \\
{[15]}\end{array}$ & + & $\begin{array}{c}+ \\
{[9]}\end{array}$ & + & & $\begin{array}{c}+ \\
{[15]}\end{array}$ & $\begin{array}{c}++ \\
{[15]}\end{array}$ & & + & & + \\
\hline Laelaps agilis & $+[9]$ & + & $\begin{array}{c}+[9 \\
15]\end{array}$ & + & & $\begin{array}{c}+[9 \\
15]\end{array}$ & $\begin{array}{c}+ \\
{[9]}\end{array}$ & $\begin{array}{c}+[9 \\
15] \\
\end{array}$ & + & + & $\begin{array}{c}+[15 \\
8]\end{array}$ & {$[15]$} & & & & \\
\hline Laelaps muris & $\begin{array}{c}+ \\
{[9]}\end{array}$ & + & + & $\begin{array}{c}+[9 ; \\
15] \\
\end{array}$ & & $\begin{array}{c}+[9 ; \\
15]\end{array}$ & + & $\begin{array}{c}+ \\
{[15]}\end{array}$ & & & [15] & & & & & + \\
\hline \begin{tabular}{|l} 
Laelaps \\
micromydis
\end{tabular} & + & & + & & & & + & + & + & + & & & & & & \\
\hline \begin{tabular}{|l} 
Laelaps \\
algericus
\end{tabular} & & & + & & & + & + & & & $\begin{array}{c}+ \\
{[9]}\end{array}$ & & & & & & \\
\hline $\begin{array}{l}\text { Eulaelaps } \\
\text { stabularis }\end{array}$ & $\begin{array}{c}+ \\
{[9]}\end{array}$ & & $\begin{array}{c}+[9 \\
15] \\
\end{array}$ & + & + & $\begin{array}{c}+[9 ; \\
15] \\
\end{array}$ & $\begin{array}{c}+ \\
{[9]}\end{array}$ & $\begin{array}{c}+[9 \\
15] \\
\end{array}$ & $\begin{array}{c}+ \\
{[9]}\end{array}$ & & $\begin{array}{c}+[15 ; \\
8] \\
\end{array}$ & [8] & $\begin{array}{c}+ \\
{[15]}\end{array}$ & & + & + \\
\hline \begin{tabular}{|l|} 
Hyperlaelaps \\
arvalis
\end{tabular} & $\begin{array}{c}+[9 \\
15]\end{array}$ & & $\begin{array}{c}+[9 \\
15]\end{array}$ & $\begin{array}{c}+ \\
{[9]}\end{array}$ & & $\begin{array}{c}++ \\
{[15]}\end{array}$ & + & $\begin{array}{c}+ \\
{[15]}\end{array}$ & & + & [15] & & & & + & + \\
\hline $\begin{array}{l}\text { Haemolaelaps } \\
\text { glasgowi }\end{array}$ & $\begin{array}{c}+ \\
{[9]}\end{array}$ & + & $\begin{array}{c}+ \\
{[9]}\end{array}$ & $\begin{array}{c}+ \\
{[9]}\end{array}$ & + & $\begin{array}{c}+ \\
{[9]}\end{array}$ & $\begin{array}{c}+ \\
{[9]}\end{array}$ & $\begin{array}{c}+[9 \\
15] \\
\end{array}$ & $\begin{array}{c}++ \\
{[9]}\end{array}$ & + & [8] & + & + & & & + \\
\hline $\begin{array}{l}\text { Hirstionyssus } \\
\text { isabellinus }\end{array}$ & $\begin{array}{c}+[9 \\
15] \\
\end{array}$ & + & $\begin{array}{c}+[9 \\
15] \\
\end{array}$ & $\begin{array}{c}+ \\
{[15]}\end{array}$ & + & $\begin{array}{c}+ \\
{[15]}\end{array}$ & + & $\begin{array}{c}+[9 \\
15] \\
\end{array}$ & $\begin{array}{c}+ \\
{[9]}\end{array}$ & & + & $\begin{array}{c}+ \\
{[15]}\end{array}$ & + & + & + & + \\
\hline $\begin{array}{l}\text { Hirstionyssus } \\
\text { musculi }\end{array}$ & $\begin{array}{c}+ \\
{[9]}\end{array}$ & & $\begin{array}{c}+[9 \\
15] \\
\end{array}$ & & + & $\begin{array}{c}+[9 ; \\
15]\end{array}$ & $\begin{array}{c}+ \\
{[9]}\end{array}$ & $\begin{array}{c}+[9 \\
15] \\
\end{array}$ & $\begin{array}{c}+ \\
{[9]}\end{array}$ & & $\begin{array}{c}+[8 \\
15] \\
\end{array}$ & $\begin{array}{c}+ \\
{[8]}\end{array}$ & [8] & & $\begin{array}{c}+ \\
{[8]}\end{array}$ & \\
\hline \begin{tabular}{|l} 
Hirstionyssus \\
ellobii
\end{tabular} & + & + & + & + & + & & + & & & & + & & & & & \\
\hline \begin{tabular}{|l} 
Hirstionyssus \\
macedonicus
\end{tabular} & & & & & + & & & & & & & & & & & \\
\hline \begin{tabular}{|l|} 
Haemogamasus \\
ambulans
\end{tabular} & $\begin{array}{c}+ \\
{[15]}\end{array}$ & & $\begin{array}{c}+ \\
{[15]}\end{array}$ & & & {$[15]$} & + & & & & {$[15]$} & & & & + & \\
\hline \begin{tabular}{|l|} 
Haemogamasus \\
nidi
\end{tabular} & $\begin{array}{c}+ \\
{[9]}\end{array}$ & + & $\begin{array}{c}+ \\
{[9]}\end{array}$ & & & $\begin{array}{c}+ \\
{[9]}\end{array}$ & $\begin{array}{c}+ \\
{[9]}\end{array}$ & $\begin{array}{c}+ \\
{[9]}\end{array}$ & & + & $\begin{array}{c}+ \\
{[8]}\end{array}$ & + & & & + & \\
\hline $\begin{array}{l}\text { Myonyssus } \\
\text { rossicus }\end{array}$ & & & + & & & {$[15]$} & & [9] & + & & & & & & & \\
\hline $\begin{array}{l}\text { Laelaps } \\
\text { pitymydis }\end{array}$ & [9] & & [9] & & & [9] & [9] & & [9] & & & & & & & \\
\hline \begin{tabular}{|l} 
Laelaps \\
multispinosus
\end{tabular} & & & {$[15]$} & [9] & & & {$[15]$} & & & & {$[15]$} & & & & & \\
\hline $\begin{array}{l}\text { Hirstionyssus } \\
\text { criceti }\end{array}$ & [9] & & [9] & & & [9] & [9] & [9] & & & & & & & & \\
\hline
\end{tabular}

Примечание: знаком «+» отмечены виды, встреченные автором

Из таблицы 1 видно, что на одной и той же территории имеются различия в данных о видовом составе сообщества гамазовых клещей. Нами не были встречены виды Laelaps pitymydis, Laelaps multispinosus и Hirstionyssus criceti, в то время как другими авторами не отмечались виды L. micromydis, H. ellobii, H. mac- edonicus. Частично различия можно объяснить разными применяемыми методиками отлова мелких млекопитающих.

По нашим данным, облигатные и факультативные гематофаги - гамазовые клещи на Самарской Луке представлены следующими видами (в скобках после 
Сорокопуд И.А.

Фауна гамазовых клещей (Gamasoidea) мелких млекопитающих.. .

03.02.00 - общая биология

названия вида указаны количество собранных экземпляров клещей и их доля в сборах):

Семейство Laelaptidae

Род Laelaps C.L.Koch, 1836

Laelaps hilaris C.L.Koch., 1836 (2030 экз., 24\%) встречается на мелких млекопитающих более чем 25 видов, но в Европейской части России является специфическим паразитом обыкновенной полевки. Облигатный гематофаг, по некоторым данным в массе размножается в гнездах полевки $[16 ; 17]$. Прокормителями также часто могут служить рыжая полевка, обыкновенная бурозубка [16]. В наших сборах является эудоминантом. Индекс обилия (далее ИО) максимален у полевки-экономки - 2,3, у обыкновенной полевки $-1,2$ и у ласки $-1,5$. Процент зараженных хозяев этим видом также высок у этих трех видов: у полевки-экономки $-41 \%$, у ласки - $29 \%$, у обыкновенной полевки $19 \%$.

По литературным данным наибольшее количество клещей этого вида прокармливают полевки рода $M i$ crotus [18]. Вероятно, именно серые полевки являются специфическими прокормителями L. hilaris и в условиях Самарской Луки и Среднего Поволжья. В литературе практически отсутствуют данные о зараженности ласок гамазидами, но судя по нашим данным L. hilaris является частым спутником этих животных. Эпизодические встречи этого вида клеща на других видах мелких млекопитающих могут объясняться либо их контактами с обыкновенной полевкой, либо тем, что L. hilaris переходит на другие виды животных там, где обыкновенная полевка не встречается [18].

Laelaps agilis Koch, 1836 (505 экз., 6\%) облигатный гематофаг, паразит желтогорлых и лесных мышей. Единично обнаруживается на других грызунах. Сопутствует своим основным хозяевам по всему их ареалу [19]. В наших сборах это доминирующий вид, заметно преобладает на желтогорлой мыши, ИО 2,3 , экстенсивность инвазии - 36\%. Среди других видов хозяев - полевки, мыши и обыкновенная бурозубка, однако из них заражены L. agilis лишь единичные особи - экстенсивность инвазии этих видов меньше 4\%.

Laelaps muris Ljungh, 1799 (172 экз., 2\%) облигатный гематофаг, специфичный паразит водяной полевки, встречается как на теле хозяина, так и в гнездах. Редко и единично обнаруживается на теле других животных. Чаще всего это свидетельствует о контакте этих животных с водяной полевкой. Водяная полевка, а вместе с ней L. muris живут преимущественно по поймам рек и берегам озер [19]. На Самарской Луке он является редким видом, заметно преобладает на водяной полевке - ИО - 3,7, ЭИ $36 \%$.

Laelaps algericus Hirst, 1925 (44 экз., 0,5\%) облигатный гематофаг. Предпочитает в качестве хозяина домовую мышь, но может встречаться и на других видах мышей [16; 19]. Крайне редкий вид. В наших сборах наибольший ИО отмечен у домовой мыши 1,7 , и максимальная экстенсивность инвазии $-23 \%$. На лесной и полевой мышах встречены единичные особи L. algericus. Служит переносчиком чумы и лимфоцитарного хориоменингита [19]. Из всех гамазид может иметь наибольшее влияние на человека, передавая через домовых мышей возбудителей инфекций.

Laelaps micromydis Zachv, 1948 (109 экз., 1,3\%) Облигатный гематофаг, паразитирует на мышималютке, реже на рыжей полевке [16]. В наших сбоpax встречаемость L. micromydis на мыши-малютке равна $8 \%$, на домовой мыши - 9\%, редкий вид. Индекс обилия - 0,3 и 0,2 соответственно.

Род Hyperlaelaps Zachvatkin, 1948

Hyperlaelaps arvalis Zachvatkin, 1948 (773 экз., 9\%) облигатный гематофаг, по литературным данным часто входит в состав доминирующих и содоминирующих видов клещей. Основными хозяевами считают обыкновенную, рыжую, водяную, красную полевок, полевку-экономку, домовую мышь, серую крысу и тундровую бурозубку [17]. Доминирующий вид. В наших сборах наивысший индекс обилия и экстенсивность инвазии наблюдается у полевкиэкономки $(И О=3, Э И=42 \%)$. Также сравнительно высокие показатели зараженности наблюдаются у водяной полевки ИО $=1,3$ и ЭИ=25\%.

Род Haemolaelaps Berlese, 1910

Haemolaelaps glasgowi Ewing, 1925 (500 экз., 6\%) типичный факультативный кровосос [16]. Предпочитает в качестве прокормителей грызунов, особенно полевок, в меньшей степени - других мелких млекопитающих $[8 ; 9,15]$. В сборах других авторов в дельте Волги этот вид оказался самым многочисленным в гнездах грызунов. Длительно голодавшие клещи способны нападать на человека [4]. Встречается на многих видах животных (около 60). Является хранителем и переносчиком туляремии, геморрагической лихорадки, клещевого энцефалита. На территории России и сопредельных стран распространен повсеместно [9]. В сообществе гамазид Самарской Луки представляется доминирующим видом.

По результатам наших исследований $H$. glasgowi также предпочитает в качестве хозяев грызунов. Заметно выше показатели у полевки обыкновенной $(И О=0,2$, ЭИ=11\%), слепушонки (ИО=1,8, ЭИ=23\%) и водяной полевки (ИО $=0,3$, ЭИ=8\%). Является полигостальным паразитом, очевидно имеет высокую степень экологической пластичности.

Род Eulaelaps Berlese, 1903

Eulaelaps stabularis Koch, 1836 (197 экз., 2,3\%) факультативный гематофаг в равной степени с зоофагией в сочетании с некрофагией, схизофагией, каннибализмом и способностью нападать на личинок иксодовых клещей. Круг хозяев насчитывает около 60 видов [16; 19]. По литературным источникам, не имеет заметной привязанности к какой-либо определенной группе хозяев, но иногда отмечается большая встречаемость на обыкновенной или рыжей полевках, возможно в силу их массовости. В наших сборах с большей экстенсивностью инвазии встречен на слепушонке - 15\%, примерно одинакова экстенсивность инвазии (более 4\%) у следующих хозяев - серая, рыжая и водяная полевки, мышь-малютка, мышь лесная, белозубка обыкновенная. Субдоминант.

Род Haemogamasus Berlese, 1889

Haemogamasus nidi Michael, 1892 (159 экз., 1,9\%) факультативный гематофаг, один из многочисленных видов гамазид в европейской части России, где основными прокормителями являются рыжая, обыкно- 
венная полевки, лесная и полевая мыши [17]. По нашим наблюдениям немногочислен и не обнаруживает определенной привязанности к каким-либо прокормителям. Встречен на 10 видах мелких млекопитающих (см. табл. 1), но в единичных экземплярах, занимает субдоминантное положение в сообществе. Максимальный индекс обилия составил всего 0,1 - на мыши-малютке.

Haemogamasus ambulans Thorell, 1872 (6 экз., 0,07\%) паразит широкого спектра хозяев: различные виды полевок, пасюки, азиатская лесная мышь, насекомоядные, хомяки и др. [13; 15]. Крайне редкий вид, нами были встречены единичные особи летом 2002 года и летом и осенью 2003 года, на обыкновенной и рыжей полевках, на кроте и полевой мыши. Другими авторами этот клещ на территории Самарской Луки встречен не был.

Род Myonyssus Tiraboschi, 1904

Myonyssus rossicus Bregetova, 1956 (2 экз., 0,02\%) является облигатным гематофагом. Редкий и малочисленный паразит рыжих и серых полевок, серой крысы, водяной полевки, домовой и лесной мышей [17; 19]. Нами было встречено всего две особи данного вида весной 2015 года на мыши-малютке и рыжей полевке.

Семейство Liponyssidae

Род Hirstionyssus Fonseca, 1948

Hirstionyssus isabellinus Oudemans, 1913 (2018, 24\%) облигатный гематофаг, один из самых многочисленных видов на территории России. Имеет широкий круг хозяев, но в основном связан с полевками (Microtidae), нередко встречается на мышах (Muridae) и насекомоядных (Insectivora), а также на других животных (более 20 видов) [17; 19]. В наших сборах занимает второе по численности место. Встречен на всех видах хозяев, кроме домовой мыши. Эудоминант, имеет высокие показатели экстенсивности инвазии: 35\% - ласка, 20\% - обыкновенная полевка, $19 \%$ - слепушонка, 22\% - водяная полевка, 16\% желтогорлая мышь и белозубка, 14\% - лесная мышь и кутора, остальные виды - менее $10 \%$. Индекс обилия у ласки - 1,8, у обыкновенной полевки $-0,8$, у слепушонки $-0,9$, у водяной полевки - 0,5 , у желтогорлой мыши - 0,6, у белозубки - 0,2, у лесной мыши - 0,3, у куторы - 0,1. H. isabellinus может передавать вирус клещевого энцефалита, F. tularensis [19]. По данным Брегетовой [4], может нападать на человека.

Hirstionyssus musculi Johnston, 1849 (322, 3,8\%) так же, как и H. isabellinus является облигатным кровососом, паразитирует на многих видах мышей: домовой, полевой, лесной, желтогорлой, мыши-малютке, на серой крысе и полевках: обыкновенной, общественной, узкочерепной, рыжей и др. H. musculi при кровососании может воспринимать вирус клещевого энцефалита, возбудителя лихорадки Ку, возбудителя бруцеллеза. Сильно восприимчив к F. tularensis. Moжет участвовать в циркуляции этих возбудителей [19]. Характерен для мышей, однако нами отмечен также на обыкновенной и рыжей полевках, малой и обыкновенной бурозубках, на слепушонке, кроте. На мышах: лесной, полевой, желтогорлой, мышималютке экстенсивность инвазии данным видом клеща у всех видов, в том числе мышей, - менее $10 \%$, индекс обилия не превышал 0,3.
Hirstionyssus ellobii Bregetova (597, 7\%), как и все представители этого рода, является облигатным гематофагом. Паразитирует на слепушонках рода Ellobius, распространен, очевидно, по всему ареалу своего хозяина [17; 19]. Для Самарской области отмечен нами впервые. На слепушонке обыкновенной паразитирует в большом количестве, ИО $=11$, ЭИ=68\%, доминирующий вид. Возможно, такие высокие показатели зараженности достигаются благодаря условиям, в которых обитает хозяин - почти постоянная изолированность от погодных условий, оптимальная увлажненность среды - что является комфортным для размножения и обитания гамазовых клещей. Однако единично данный вид встречается и на других видах млекопитающих - обыкновенной полевке, обыкновенной бурозубке, рыжей полевке, полевке-экономке, водяной полевке и полевой мыши.

Hirstionyssus macedonicus Hirst, 1921 (5, 0,06\%) является специфичным для семейства Слепышовых [20]. Для Самарской области крайне редкий вид, отмечен нами впервые. Согласно литературным данным, встречался на территории Центрального Предкавказья, Ставропольского края, Саратовской области $[4 ; 20]$. Нами обнаружено 5 особей данного вида на одной слепушонке обыкновенной в осенний период 2009 года.

Необходимо отметить, что определение вида Hirstionyssus transiliensis, отмечаемого нами в ранних работах [21], было ошибочным из-за схожей морфологии видов. На настоящий момент видовая принадлежность уточнена, особи были отнесены к виду $H$. isabellinus.

В результате наших исследований подтверждаются литературные данные о том, что степень специфичности видов и групп гамазид в отношении хозяев находится в определенной зависимости от типов паразитизма [18]. Среди гнездово-норовых паразитов, в частности факультативных кровососов семейств Laelaptidae и Haemogamasidae, сравнительно много форм с невысокой степенью специфичности, в наших сбоpax это виды: E. stabularis, H. glasgowi, H. nidi. Они встречаются практически на всех видах млекопитающих, встреченных в наших исследованиях. Очевидно, что для этих видов в первую очередь важна среда обитания хозяина.

Среди эпизойных паразитов обладают широкой экологической пластичностью в отношении хозяина такие виды, как H. isabellinus, H. musculi, L. hilaris. Они распространены на больших территориях, и хотя в литературе отмечено, что характерными хозяевами для них являются полевки (в основном обыкновенная) и мыши (Muridae) [8; 9, 15, 19], эти виды клещей встречаются на широком круге хозяев, в том числе на ласке и различных насекомоядных. Возможно, в местах, где не встречаются специфичные хозяева, они с легкостью переходят на другие виды прокормителей.

Наибольшая степень специфичности и более узкая экологическая пластичность наблюдается у форм, переходящих к постоянному наружному паразитизму - роды Laelaps и Hirstionyssus. Для представителей некоторых видов этих родов характерна приуроченность паразитов к систематическим группам или даже отдельным видам хозяев. Так, в наших сборах это виды L. agilis (хозяин - желтогорлая мышь), L. muris (хозяин - водяная полевка), L. micromydis (хозяин - мышь- 
малютка), L. algericus (хозяин - мышь домовая), H. arvalis (хозяин - полевка-экономка, водяная полевка), особенно хорошо отражает данный тип паразитизма вид H. ellobii (хозяин - слепушонка обыкновенная).

Доминирующее положение среди клещей на грызунах занимают широко распространенные виды, облигатные гематофаги - L. hilaris, H. isabellinus эудоминанты, H. ellobii, H. arvalis, L. agilis и факультативный гематофаг - H. glasgowi - доминанты. Эти виды представляют особый интерес в виду своей массовости, так как с их помощью возможно изучение различных аспектов паразитирования на мелких млекопитающих, выявление закономерностей паразито-хозяинных отношений.

\section{СПИСОК ЛИТЕРАТУРЫ:}

1. Тарасов В.В. Медицинская энтомология. М.: Изд-во Московского университета, 1996. С. 307.

2. Агапова И.Н. К фауне и экологии гамазовых клещей грызунов в эпидочагах Воронежской области // Первое акарологическое совещание АН СССР. М.Л.: Наука, 1966. С. 7-8.

3. Белозеров В.Н. Влияние влажности на поведение гамазовых клещей // 9-е совещ. по паразитол. проблемам: Тез. докл. М.-Л., 1957. С. 16-17.

4. Брегетова Н.Г., Колпакова С.А. Гамазовые клещи (Parasitiformes, Gamasoidea) - паразиты мелких мышевидных грызунов и обитатели их гнезд в дельте Волги // Паразитологический сборник. Т. XVI. М.-Л.: Изд-во АН СССР, 1956. С. 184-195.

5. Борисова В.И., Назарова И.В. Фауна и экология гамазовых клещей землероек южного аванпоста тайги в Волжско-Камском крае (Acarina, Gamasoidea) // Паразитология. 1981. Т. 15, Вып. 1. С. 21-26.

6. Винарская Н.П., Винарский М.В. Ландшафтнозональная изменчивость видового богатства и обилия гамазовых клещей, связанных с мелкими млекопитающими на юге Западной Сибири // Биосфера Земли: прошлое, настоящее и будущее: Материалы конф. молодых ученых, 21-25 апреля 2008 г. Екатеринбург: Изд-во «Гошицкий», 2008. С. 51-59.

7. Гаджиев А.Т. Гамазовые клещи Кавказа. Баку, 1983. $180 \mathrm{c}$.

8. Кириллова Н.Ю., Кириллов А.А. Эктопаразиты насекомоядных млекопитающих (Insectivora) Самарской Луки // Самарская Лука. 2008. Т. 17, № 1(23). С. 91-97.

9. Кириллова Н.Ю., Кириллов А.А. Эктопаразиты грызунов (Rodentia) Самарской Луки // Известия Са- марского научного центра РАН. 2008. Т. 10, № 2. C. $479-487$.

10. Симак С.В., Бабаев Т.О. Ловушка для грызунов. Патент на полезную модель № 145269. Зарегистрировано в Государственном реестре полезных моделей Российской Федерации 11 августа 2014 г.

11. Симак С.В., Бабаев Т.О. Зависимость зараженности мелких млекопитающих Самарской Луки природно-очаговыми инфекциями // Материалы X международной научной конференции. Т. I. Самара: СГОАН, 2014. С. 140-148.

12. Соколов Г.А., Тимошкина О.А., Сенотрусова М.М. Отлов и первичная обработка мелких грызунов и насекомоядных: Метод. разработка. Красноярск: Краснояр. гос. ун-т, 2005.

13. Брегетова Н.Г. Гамазовые клещи (Gamasoidea) // Определители по фауне СССР № 61. М.-Л.: Изд-во АН СССР, 1956.

14. Бобринский Н.А., Кузнецов Б.А., Кузякин А.П. Определитель млекопитающих СССР. Изд-е 2-е. М.: Просвещение, 1965. 384 с.

15. Корнеев В.А. Экологические связи гамазовых клещей (Arachnida, Gamasoidea) с мелкими млекопитающими в лесных биотопах среднего Поволжья // Экология. 2003. № 2. С. 147-151.

16. Никулина Н.А. Эколого-фаунистическая характеристика некоторых видов паразитических гамазовых клещей мелких млекопитающих в природных комплексах России // Вестник ИрГСХА. Вып. № 32. Иркутск, 2008. С. 55-82.

17. Никулина Н.А. Население гамазовых клещей мелких млекопитающих в природных комплексах России: дис. ... д-ра биол. наук. Красноярск, 2007. 344 с.

18. Земская А.А. Паразитические гамазовые клещи (Gamasoidea) фауны CCCP: автореф. дис. ... д-ра биол. наук. М., 1968. 30 c.

19. Земская А.А. Паразитические гамазовые клещи и их медицинское значение: монография. М.: Медицина, 1973. С. 83-151.

20. Жильцова А.Ю. Гамазовые клещи (Acari: Gamasina) Центрального Предкавказья: дис. ... канд. биол. наук. М., 2010. 133 с.

21. Сорокопуд И.А., Симак С.В., Бабаев Т.О., Кожевникова М.В. Фауна и экология гамазовых клещей мелких млекопитающих Самарской Луки // Материалы XI международной научной конференции. Т. I. Самара: СГОАН, 2015. С. 134-146.

\section{FAUNA OF GAMASINA MITES (GAMASOIDEA) OF SMALL MAMMALS OF A NATURAL REGION «SAMARSKAYA LUKA»}

(C) 2016

I.A. Sorokopud, postgraduate student of the Chair of Ecology and Environmental Protection Samara State Oblast Academy (Nayanova), Samara (Russia)

Abstract. Data on fauna of gamasina mites parasitizing on small mammals are provided in article. Data are obtained during long-term monitoring of an ecological complex of small mammals of a natural and territorial complex «Samarskaya Luka», which is realized since 1999. Also data on fauna of gamasina mites in 14 years of researches (2000-2003, 2005, 2007-2015 years), including literary data about the gamasina mites of this territory, are generalized and analysed. Specific accessory of 7439 individuals of mites, seven childbirth of three families relating to fifteen types is defined. Parasitizing the gamasina mites on 16 species of small mammals, including groups rodents, soricomorpha, carnivora (least weasel) is established.

Domination of separate species of mites is revealed, so to eudominant Laelaps hilaris and Hirstionyssus isabellinus are belong, dominants are - Hirstionyssus ellobii, Haemolaelaps glasgowi, Hyperlaelaps arvalis, L. agilis. Myo- 
nyssus rossicus, L. algericus, Haemogamasus ambulans and Hirstionyssus macedonicus were extremely rare species met in single copies. For the first time for this territory types of H. ellobii, L. micromydis, H. ambulans, H. macedonicus are noted.

Conclusions on degree of a confinedness of parasites to certain types of hosts are drawn. Monohostal types: $L$. agilis (the host - a yellow-necked mouse), L. muris (the host - a tundra vole and a water vole), L. micromydis (the host - a small mouse), L. algericus (the host - a house mouse), $H$. arvalis (the host - a tundra vole and a water vole), $H$. ellobii (the host - a northern mole vole). Polihostal: H. musculi, L. hilaris, H. isabellinus, H. glasgowi, E. stabularis, H. nidi.

Keywords: gamasina mites; environmental monitoring; small mammals; Samarskaya Luka; Samara Region; parasites; parasites-hostals complexes; rodents; insectivorous; shrews; contamination; abundance index; extensiveness of an invasion; extent of domination; parasite-hostal confinedness.

\title{
УДК 582.232/275.574.5.633
}

\section{АЛЬГОФЛОРА СРЕДНЕГО ТЕЧЕНИЯ РЕКИ ЗАРАФШАН И ЕЕ ВЗАИМОСВЯЗЬ С ИНДИКАТОРНО-САПРОБНЫМИ ВИДАМИ}

(C) 2016

\author{
Й.Ш. Ташпулатов, ассистент кафедры плодоовощеводства и виноградарства \\ Самаркандский сельскохозяйственный институт, Самарканд (Республика Узбекистан)
}

\begin{abstract}
Аннотация. Изучены таксономические, флористические и индикаторно-сапробные особенности альгофлоры среднего течения реки Зарафшан, проведен сравнительный экологический анализ. Исследование проведено на 10 наблюдательных точках, распределенных по течению реки. Эти точки выбраны по расположению таких загрязняющих источников реки, как каналы, крупные коллекторы, сточные воды бытовых и промышленных источников крупных городов. Выявлено, что в реке имеется 331 вид и разновидность водорослей. Они относятся к 81 роду, 38 семействам, 16 порядкам, 11 классам и 5 отделам. Из них 97 видов и разновидностей являются индикаторно-сапробными водорослями. В первых трех наблюдательных точках экологические условия почти одинаковы. В этих пунктах определено 119 видов и разновидностей, из них 37 видов являются индикаторно-сапробными. Средний сапробный индекс - 1,27; $\alpha$ олигосапробы, класс - 2, разряд - 2b. Более чистая вода в 4-7 наблюдательных пунктах реки, здесь определено 200 видов, из них 56 видов считается индикаторно-сапробными. Средний сапробный индекс - 1,61; $\beta^{1}$ мезосапроб, класс - 3, разряд - 3а, вода достаточно чистая. На 8-10 наблюдательных пунктах выявлено всего 125 видов, из них 44 вида считается индикаторно-сапробными видами. Средний сапробный индекс достиг 1,$84 ; \beta^{1}$-мезосапроб, класс - 3, разряд - 3а, вода достаточно чистая. По течению реки постепенно повышается сапробный индекс, сапробный уровень водорослей и загрязнение воды.

Ключевые слова: Заравшан; альгофлора; водоросли; таксономия; систематика; флористика; сравнительный экологический анализ; индикаторно-сапробные виды; индекс сапробности; загрязнение воды; Узбекистан; Самаркандская область; Навоийская область.
\end{abstract}

Водоросли - начальное звено трофической цепи, основной продуцент органического вещества в водоемах и наиболее перспективный объект для оценки состояния водных экосистем. Инвентаризация альгофлоры актуальна потому, что экосистемы водоемов чрезвычайно быстро реагируют на изменения климатических и других физико-географических условий, а также на последствия хозяйственной деятельности человека. Качественные и количественные исследования водорослевых сообществ - основной этап, открывающий возможность для экологического мониторинга. В нашей республике и на других территориях в последние годы в этом направлении выполнено много практических работ [1, с. 104-106; 2, с. 49; 3 , c. $125 ; 6$, с. $127-130]$.

Река Зарафшан является трансграничной. Верхнее течение начинается с Зарафшанского ледника горного Таджикистана, среднее и нижнее течения протекают по долине, которая расположена между Зарафшанским и Туркестанским хребтами в республике Узбекистан. Общая длина реки достигает примерно 870 км. Длина среднего течения реки составляет более 200 км. Альгофлора среднего течения р. Зарафшан, наличие сапробно-индикаторных видов и их Самарский научный вестник. 2016. № 2 (15) роль в определении качества воды не изучены. В реку впадает несколько каналов, коллекторы, арыки, сточные воды бытовых и промышленных отраслей. Это отрицательно влияет на физико-химический состав воды и разнобразие флоры и фауны реки.

Среднее течение реки Зарафшан начинается от кишлака Раватхужа Ургутского района Самаркандской области и завершается у поселка Янгибазар Хатирчинского района Навоийской области (200 км). В этом регионе довольно высокая плотность населения, развита промышленность, вблизи реки есть крупные города и хорошо развито орошаемое земледелие.

За годы исследований изучены таксономические, флористические и индикаторно-сапробные особенности альгофлоры среднего течения реки Зарафшан, проведен сравнительный экологический анализ. Исследование проведено на 10 наблюдательных точках, распределенных по течению реки. Эти точки выбраны по расположению таких загрязняющих источников реки, как каналы, крупные коллекторы, сточные воды бытовых и промышленных стоков крупных городов. В этих наблюдательных точках собраны альгологические пробы по общепринятым методикам [4, c. 350]. С помощью определителей (Определитель 